Vol. 2, $n^{\circ} 1 \mid 1998$

Varia

\title{
Kingston (Rebecca), Montesquieu and the Parlement of Bordeaux
}

Genève, Droz (Collection Histoire des idées et critique littéraire, $n^{\circ} 324$ ), 1996, 329 pp.

Martin Dinges

\section{(2) OpenEdition}

\section{Journals}

Electronic version

URL: https://journals.openedition.org/chs/1000

DOI: $10.4000 /$ chs. 1000

ISSN: 1663-4837

Publisher

Librairie Droz

\section{Printed version}

Date of publication: 1 January 1998

Number of pages: 135-136

ISBN: 2-600-00279-0

ISSN: 1422-0857

Electronic reference

Martin Dinges, "Kingston (Rebecca), Montesquieu and the Parlement of Bordeaux", Crime, Histoire \&

Sociétés / Crime, History \& Societies [Online], Vol. 2, $n^{\circ} 1$ | 1998, Online since 03 April 2009, connection on 23 March 2022. URL: http://journals.openedition.org/chs/1000 ; DOI: https://doi.org/10.4000/chs. 1000 


\section{Compte rendu Review}

Kingston (Rebecca), Montesquieu and the Parlement of Bordeaux, Genève, Droz (Collection Histoire des idées et critique littéraire, $\left.n^{\circ} 324\right), 1996,329 \mathrm{pp}$.

Kingston's endeavour to reconstruct the political theory of Montesquieu takes into account his practical experience as a member of the Parlement of Bordeaux. There, Montesquieu acted as a judge in the chamber of criminal justice for the exceptionally long period of ten and a half years (1715-1724), before he sold his office. Kingston characterizes the judicial socialization of Montesquieu as dominated by practice in the current jurisprudence. She then reconstructs the political ideology of those Arrêts du Parlement which Montesquieu coauthored. The Parlement defended in opposition to the king, the local bien public, leaving any religious legitimacy aside. It also outlined its own competence of administration against the clientelistic approach of the city council. As the better guarantee for grain supply, it defended the importance of free trade against state intervention. Kingston calls this discourse an «associational mode of argument» (p. $94 \mathrm{ff}$.), because it considers individual and collective interests and the values linked to them as an important basis of politics. The emerging state should not only respect this basis, but rely on it. Kingston's reconstruction of the Parlement's criminal justice provides us with the standard information about the practice of a royal court. An important part of the caseload was caused by the corruption and poor jurisdiction of lower courts. Like other higher courts, the Tournelle modified half of the death penalties of the lower courts. Moreover, since torture was used less and less, moderation was advocated.

By analysing Montesquieu's theoretical works from the Bordeaux years without referring much to secondary literature, Kingston shows how Montesquieu distanced himself from the model of heroic politics of the Romans. In its place he suggested stability and welfare as better political orientations. As a result of Montesquieu's analysis of the Romans' success, Kingston presents Montesquieu's argument that the rulers should encourage those forms of associations which, according to him, improve morality, the foundation of every good regime. From these readings Kingston derives as the fundamental idea of the «Esprit des lois» that the multiplicity of associations leads to very different requirements of law. No universal model can be applied to all situations.

Montesquieu claims that the state should use criminal justice as a means to manage existing forms of social control not pretending to dominate them. Thus the state should take into account existing fears (e.g. to be socially defamed), and not try to terrorize (Hobbes) the citizen. Montesquieu supposes this to be inefficient. In general, law should be used only as the last solution for a conflict. In this chapter 
Kingston points to some connections to Montesquieu's judicial practice: he suggests not to punish words - as the Parlement did not treat many cases of lèse-majesté. The principle that deterrence must be measured is related to the practice of the court. Both findings are commonplace. The first, because the cases of lèse-majesté occurred rarely. The second, because clemency of upper instances appeared in all French higher courts in the 18th century.

As a result Kingston argues that Montesquieu was «not the defender of» Parlement «as one form of intermediary body». He pleaded for a «strong central and uniform application of criminal justice. It serves in part as a prerequisite for his theory of political liberty".

This study of the social history of ideas shows connections between the arguments of the judicial company in which Montesquieu served and his theoretical ideas. But, where Kingston approaches the court's practice, the relation between Montesquieu's ideas and the judicial practice is very commonplace. A more sophisticated (e.g. quantitative) analysis of the courts' and Montesquieu's language might have led to more precise results. Reflections about the sociopolitical positions of the high judges in Ancien Régime France (cf. M. Andrews: Law, Magistracy, and Crime in Old Regime Paris, 1735-89, Cambridge, 1994), and about the relation between power and discourse might have enriched this «social history of ideas». But it is still possible that the book might lead to a closer link of the research on the history of ideas with the social realities of Ancien Régime justice, even if the nature of this link should be refined methodologically.

Martin Dinges,

Institut für Geschichte der Medizin

Robert Bosch Stiftung (Stuttgart, FRG)

\section{ERRATUM}

\section{CHS, 1997, Vol. 1, n² 2, p. 117}

La référence de l'ouvrage suivant, dont un compte rendu est paru dans le précédent numéro de CHS, était incomplète; il faut lire:

Durand (Bernard), Arbitraire du juge et consuetudo delinquendi: la doctrine pénale en Europe du XVIe au XVIII siècle, Montpellier, Publications de la Société d'histoire du droit et des institutions des anciens pays de droit écrit, V, 1993. 